\title{
SKEMA PEMBAGIAN MANFAAT DAN STAKEHOLDERS TERHADAP PENGELOLAAN HUTAN DAMAR (Agathis labilardieri Warb.) DISTRIK BIAK TIMUR KABUPATEN BIAK NUMFOR
}

\section{(Benefit Sharing Schema and Sackholders on the Agathis labilardieri Warb. Forest Management in East Biak Sub-District)}

\author{
Jhon Arnold Maran ${ }^{1}$, Jonni Marwa ${ }^{1 凶}$ dan Anton Silas Sinery ${ }^{1}$ \\ Jurusan Kehutanan, Fakultas Kehutanan Universitas Papua Manokwari, Papua Barat, \\ 98314. Tlp/Fax: +62986211065. \\ Penulis Korespondensi: Email: jonnimarwa@gmail.com \\ Diterima: 03 Feb 2017| Disetujui: 17 Mar 2017
}

\begin{abstract}
Abstrak
Tujuan penelitian ini ialah mengkaji skema pembagian manfaat sumberdaya hutan dan mendukung peran masyarakat adat di distrik Biak Timur. Metode yang digunakan yaitu deskriptif dan observasi dengan teknik studi kasus, wawancara semi struktural dengan subjek berupa masyarakat pemilik hak ulayat, serta stakeholder yang terkait. Hasil penelitian menunjukkan terdapat dua skema pembagian manfaat yaitu skema berbasis uang melalui proses pembayaran uang kepada masyarakat pemilik hak ulayat sesuai produk kayu yang dibeli dan berbasis dampak yaitu melaui uang yang diterima pemilik hak ulayat terkait dengan kegiatan-kegiatan pemeliharaan dan pelestarian kawasan hutan yang rusak. Terdapat kegiatan rehabilitasi dan pemulihan kawasan hutan dan meningkatkan peran dan keterlibatan masyarakat dalam merehabilitasi hutan dan lahan. Dengan adanya keterlibatan stakeholder memberikan manfaat bagi keberlanjutan manfaat dan pengeolaan hutan Damar. Kata kunci: Skema pembagian manfaat, stakeholder, hutan damar, rehabilitasi, Biak Timur

Abstract

The objective of the study was to identify benefit sharing schema of natural forest resource and contribute to the local community's role in east Biak sub-district. Descriptive and field observation through case study, semi structural interview with customary community as the main subjectas well as related stakeholders who closel involved. The result indicated two benefit sharing schemas which were money based-schema that involved active payment given to the customary community which based on the purchased timbers. The another one was impact based-schema that has been lie heavily on the maintenance and forest areal recovery from its disturbances. In addition, rehabilitation has been one of the solutions for sustainability. Through the engangement of stakeholders, the continuity and benefit value from the Agathis will be impacful in the area.
\end{abstract}

Keywords: Benefit sharing schema, stakeholders, Agathis forest, rehabilitation, East Biak

\section{PENDAHULUAN}

Hutan memberikan manfaat multifungsi bagi kehidupan manusia, baik manfaat sosial, ekonomi, lingkungan bahkan religius dari generasi ke generasi. Oleh sebab itu, masyarakat yang hidup di dalam dan sekitar hutan sangat bergatung 
pada berbagai manfaat yang dihasilkan dari hutan. Di dalam suatu ekosistem hutan terkandung sumberdaya kayu, hasil hutan bukan kayu dan jasa lingkungan yang nilainya sangat tinggi. Sumberdaya kayu sampai saat ini masih menjadi andalan bagi kelangsungan hidup suatu masyarakat dibandingkan dengan HHBK dan jasa lingkungan lainnya karena peranannya yang tidak sudah dirasakan dari masa ke masa sedangkan HHBK dan jasa lingkungan belum banyak dimanfaatkan karena sering dinilai sangat rendah secara ekonomi. Kayu sebagai sumber bahan bangunan, sumber energi dan sumber obat-obatan telah dikenal masyarakat karena itu aktivitas untuk memanfaatkan kayu terus meningkat seiring dengan bertambahnya waktu. Pemanfaatan sumberdaya seperti kayu yang melebihi kapasitasnya akan menimbulkan degradasi dan kelangkaan sumberdaya tersebut apalagi kalau sumberdaya itu jenisnya terbatas.

Masyarakat Kampung Rimba Jaya, Distrik Biak Timur sudah bertahun-tahun memanfaatkan kayu damar (Agathis labilardieri Warb.) dalam memenuhi kebutuhan hidup. Kawasan hutan Parieri di Kampung Rimba Jaya Distrik Biak Timur merupakan Taman Hutan Raya yang luasnya \pm 2.200 ha yang dikenal dengan jenis tanaman endemiknya yaitu damar dan merupakan tegakan alam yang sudah dikelola sejak zaman Belanda. Kawasan ini juga berfungsi sebagai penyangga, pusat benih dan dapat dikembangkan sebagai obyek wisata. Selain getah kayu, bagian ranting dan batang juga digunakan oleh masyarakat. Tercatat bahwa damar-damar di hutan tersebut pernah dipasarkan ke luar daerah dan menghasilkan pendapatan bagi masyarakat sekitarnya melalui penjualan damar. Namun saat ini dengan makin meningkatnya aktivitas pembangunan di sekitar kota Biak maka aktivitas pemanfaatan kayu damar ini terus meningkat dan menimbulkan degradasi yang makin meluas.

Penebangan yang dilakukan di hutan Agathis berada di dalam wilayah hak-hak masyarakat adat telah menguras sumberdaya tersebut dan belum memberikan manfaat yang wajar bagi masyarakat adat. Penebangan kayu damar cenderung tidak transparan dan mengabaikan hak-hak masyarakat adat. Pada tingkatan masyarakat sering muncul sengketa-sengketa internal yang terkait dengan pengambilan keputusan sampai pembagian manfaat pengelolaan hutan yang dinilai tidak adil bagi pemerintah Kabupaten Biak Numfor.

Permasalahan pembagian manfaat yang tidak adil diakui menjadi titik konflik dalam pengelolaan kawasan hutan damar tersebut. Pembagian manfaat yang tidak adil telah menimbulkan konflik karena pemindahan hak-hak masyarakat adat kepada para pembeli kayu yang tidak transparan dan tidak menghormati hak masyarakat lokal sehingga secara struktural telah menghilangkan sumbersumber pendapatan langsung dari masyarakat adat. Kehilangan sumber penghidupan berupa hasil hutan memiliki korelasi dengan kemiskinan di dalam masyarakat. Oleh sebab itu diperlukan skema pembagian manfaat yang wajar dan strategi pengelolaan yang lebih bijaksana terhadap hutan damar di wilayah kampung Rimba Jaya. Adapun tujuan dari penelitian ini yaitu ingin mengkaji skema pembagian manfaat sumberdaya hutan yang wajar dan mendukung penghormatan terhadap hak dan keberlangsungan hidup masyarakat 
adat dan sumberdaya hutannya, serta mengidentifikasi dan memetakan stakeholders berdasarkan pengaruh dan kepentingan

\section{METODE PENELITIAN}

Penelitian ini dilakukan pada hutan Damar (Agathis labilardierWarb) Kampung Rimba Jaya Distrik Biak Timur Kabupaten Biak Numfor Provinsi Papua dengan waktu kurang lebih 4 bulan pada thaun 2015. Dalam penelitian ini digunakan metode deskriptif, dan observasi dengan teknik studi kasus dan wawancara semi struktural. Subyek dalam penelitian adalah masyarakat pemilik hak ulayat, masyarakat umum, tokoh pendidikan, tokoh pemuda, tokoh agam, Distrik Biak Timur, kepala suku, Pemilik usaha kayu (Suasta), SEKDA, keamanan (polisi), LSM lokal, danKPHL Kabupaten Biak Numfor.

\section{Penentuan Responden}

Responden yang didata dalam penelitian ini berupa responden umum dan responden kunci.Pengambilan contoh responden dilakukan secara purposif dengan pertimbangan masyarakat pemilik hak ulayat, masyarakat lain yang berdomisili di alam kampung di sekitar hutan Damar yang menerima manfaat sumberdaya hutan. Responden kunci pemerintah daerah, LSM dan suasta yang memanfaatkan sumberdaya hutan. Variabel yang diamati dalam penelitian ini terdiri dari: karakteritistik pengusahaan hutan, skema pembagian manfaat yang diperoleh dan para pihak yang terlibat dalam penentuan dan pengelolaan skema pembagian hasil.

\section{Sumber Data}

Data yang dikumpulkan dalam penelitian ini meliputi data primer dan data sekunder.

Data primer diperoleh dengan cara observasi lapang dan wawancara langsung dengan panduan kuisioner. Sumber responden dibatasi hanya pada masyarakat pemilik hak ulayat dan stakeholders yang memiliki kepentingan pembagian manfaat sumberdaya hutan di wilayah Kabupaten Biak Numfor. Data sekunder diperoleh dari instansi-instansi terkait seperti dinas Kehutanan, dinas Perindustrian, BPS, dan LSM. Data tersebut berupa dokumen-dokumen atau hasil-hasil penelitian sebelumnya.

\section{Kepentingan}

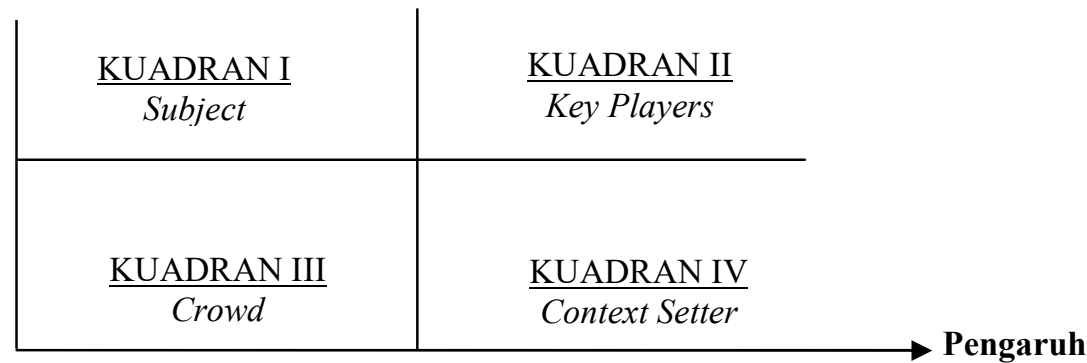

Gambar 1. Ilustrasi pemetaan kepentingan dan pengaruh stakeholders. 


\section{Analisis Data}

Data yang diperoleh dalam penelitian ini dianalisa secara kualitatif dengan suatu alat analisis yaitu berupa analisis stakeholders. Analisis stakeholders adalah suatu pendekatan sistematis untuk mengumpulkan informasi tentang siapasiapa, mengapa dan bagaimana skema pembagian manfaat sumberdaya hutan damar di wilayah masyarakat adat kampung Rimba Jaya Distrik Biak Timur Kabupaten Biak Numfor dan selanjutnya diolah dengan pendekatan tabulasi dan dianalisis secara deskriptif. Analisis matriks-plot digunakan untuk melihat kepentingan dan pengaruh stakeholders terhadap kegiatan pengembangan KPHL Biak. Selanjutnya, skala kepentingan dan pengaruh dari hasil analisis plot ini dibagi dua sehingga diperoleh empat kuadran sesuai Gambar 1.
Data yang diperoleh selanjutnya diolah dengan pendekatan tabulasi dan dianalisis secara deskriptif. Untuk menduga nilai manfaat ekonomi bagi masyarakat digunakan informasi uang yang diberikan atau dibayarkan sebagai bentuk ganti rugi harga kayu.

\section{Nilai manfaat $=\mathrm{V} \times \mathbf{P}$}

Dimana :

$\mathrm{V}=$ Jumlah volume kayu $\left(\mathrm{m}^{3}\right)$;

$\mathrm{P}=$ Harga minimal kompensasi masingmasing jenis kayu.

Untuk menilai aktifitas pembagian manfaat yang adil digunakan pendekatan prinsip-prinsip pembagian manfaat yang adil menurut (Mohhamed 2011; Wagstaff 1994; Maiese 2003 dalam Marwa 2015) sebagai berikut:

Tabel 1. Klasifikasi skema pembagian manfaat berdasarkan syarat pemenuhuannya

\section{Pemenuhan Syarat}

Equality

Equity

Needs-base

Berbasis Hak

Pro Poor

Transparency

Additionality

\section{Skema Pembagian Manfaat}

\begin{tabular}{llllll}
\hline $\mathrm{A}$ & $\mathrm{B}$ & $\mathrm{C}$ & $\mathrm{D}$ & $\mathrm{E}$ & $\mathrm{F}$
\end{tabular}

$+/-\quad+/-\quad+/-\quad+/-\quad+/-\quad+/-$

$+/-+1-+1-+1-+1-+1-$

$+/-+1-+1-+1-+1-+1-$

$+1-+1-+1-+1-+1-+1-$

$+1-+1 /-+1-+1-+1-+1-$

$+/-+1-+1-+1-+1-+1-$

$+/-+1-+1-+1-+1-$

Keterangan : + = syarat dipenuhi ; - = Syarat tidak dipenuhi

Equality (kesetaraan) - setiap orang menerima manfaat/jumlah yang sama

Equity (Keadilan) _ $\quad$ Jumlah dari sumberdaya yang diterima cocok atau sesuai dengan kontribusi atau kebutuhan.

Needs-base Distribusi pembagian manfaat berdasarkan kepuasan atas kebutuhan dasar bagi setiap orang. Berbasis hak-distribusi sistem pertanahan dalam hal (promosi dan perlindungan) hak-hak masyarakat.

Pro Poor $\quad-\quad$ mempertimbangkan dampak dari pengaturan kesejahteraan bagi rakyat miskin dan yang rentan terhadap kemiskinan.

Transparency $\quad-\quad$ Pembagian manfaat dilakukan secara transparan

Additionality _ $\quad-\quad$ Tambahan penerimaan/pendapatan dapat dilakukan dalam kegiatan pembagian manfaat

Semakin banyak syarat dapat dipenuhi maka skema pembagian manfaat tersebut semakin adil dan efisien.

4

@ Asosiasi Peneliti Biodiversitas Papuasia - Fakultas Kehutanan UNIPA 


\section{HASIL DAN PEMBAHASAN}

\section{Karakteristik Pengusahaan Hutan}

Secara agregat kawasan hutan Biak Numfor memberikan kontribusi sebesar 1,2\% terhadap luas keseluruhan kawasan hutan di provinsi Papua. Hutan yang terluas di wilayah Biak Numfor adalah hutan dengan fungsi lindung yakni seluas 121.593,50 hektar. Selain kawasan hutan lindung terdapat hutan produksi tetap sebesar 25.747,31 hektar dan hutan produksi terbatas sebesar 35.539,34. Luasan hutan yang relatif besar ini menyimpan potensi hasil hutan yang besar pula yang terutama sektor kayu. Dalam memenuhi kebutuhan kayu lokal pemerintah mengeluarkan ijin sah lainnya (ISL) kepada masyarakat baik yang memiliki perusahaan seperti $\mathrm{CV}$ atau PT maupun secara perorangan. Jumlah pemegang ijin sah lainnya berfluktuasi, namun masyarakat asli Biak Numfor sendiri jarang yang memegang ijin tersebut, namun kebanyakan orang non Papua. Masyarakat lokal Biak Numfor karena memiliki hak ulayat sehingga hanya menjual tegakan pohon kepada para pemegang ijin dan pemilik stand kayu atau perusahaan meubel.

Secara administrasi proses penjualan kayu lokal hanya menggunakan Faktor Angkutan Kayu Olahan (FAKO) yang dikeluarkan oleh dinas Kehutanan Biak Numfor. FAKO memiliki batas waktu maupun jumlah kubikasi yang akan dijual. Penjualan dapat dilakukan langsung kepada produsen atau melalui stand kayu yang tersedia. Namun aktivitas penebangan kayu di hutan dilakukan atas kesepakatan pembeli dan penjual. Hal ini juga terjadi pada hutan
Agatis di Kampung Rimba Jaya Distrik Biak Timur.

Aksesibilitas masyarakat hukum adat dalam memanfaatkan hutan ulayat dan penentuan besarnya nilai jual kayu menjadi semakin terbuka luas. Demikian pula peluang masyarakat adat dalam menyuarakan pendapat mereka terbuka lebar, namun karena keterbatasan, baik dari segi modal dan teknologi, serta kebijakan terhadap penguatan kapasitas masyarakat dari pemerintah belum maksimal, sehingga peluang tersebut dimanfaatkan oleh rent seeking (pencari keuntungan) untuk menjadikan masayarakat sebagai alat legalitas dalam kegiatan pengusahaan hutan.

Adanya pembayaran kayu log atau kayu olahan dari jenis kayu damar secara langsung yang dilakukan dan juga jenisjenis kayu lain di wilayah kabupaten Biak Numfor memberikan karakteristik tersendiri.

\section{Skema Pembagian Manfaat Hutan Damar}

Pembagian manfaat hutan damar dilakukan oleh pemilik usaha stand kayu dan usaha meubel serta pemerintah dalam hal ini dinas Kehutanan dan KPHL Biak Numfor. Pembagian manfaat ini telah memberikan beberapa manfaat bagi masyarakat hukum adat pemilik hak ulayat pada hutan damar melalui skema berikut ini :

\section{Skema Berbasis Uang}

Skema berbasis uang merupakan bentuk yang umum dilakukan oleh semua perusahaan atau pengusaha di bidang kehutanan di tanah Papua. Skema ini berkaitan dengan penghargaan terhadap masyarakat hukum adat yang diberikan dalam bentuk moneter (uang) atau yang sering disebut juga dengan sistem fee. 
Dalam studi ini ditemukan bahwa setiap pengusaha meubel, penampung kayu dan kios kayu di sekitar Kota Biak membayar sejumlah uang kepada masyarakat pemilik hak ulayat sesuai produk kayu yang dibeli yaitu balok Rp. 1.500 .000 dan papan Rp.2.000.000 untuk melakukan penebangan kayu damar di kawasan hutan yang menjadi hak milik mereka dan mengantar langsung ke meubel atau stand kayu. Kios kayu di kota Biak berjumlah 13 unit, meubel 17 unit dan penampung kayu untuk kebutuhan kontruksi sebanyak 5 unit. Kayu-kayu ini belum termasuk yang dipakai untuk pembangunan yang di kampung-kampung.

Tabel 2. Bentuk dan nilai manfaat skema berbasisi uang di Kota Biak

\begin{tabular}{|c|c|c|c|c|c|}
\hline No. & Bentuk Manfaat & $\begin{array}{c}\text { Jumlah kayu } \\
\text { yang dijual } \\
\left(\mathrm{m}^{3}\right)\end{array}$ & $\begin{array}{l}\text { Haraga } \\
\text { (Rp) }\end{array}$ & $\begin{array}{c}\text { Estimasi Nilai } \\
\text { Manfaat }(\mathrm{Rp}) / \mathrm{Thn}\end{array}$ & $\begin{array}{l}\text { Penerima } \\
\text { Manfaat }\end{array}$ \\
\hline 1. & Kios Kayu & 3.330 & 1.500 .000 & 4.995 .000 .000 & Masyarakat \\
\hline 2. & Meubel & 15.707 & 1.500 .000 & 220.510 .500 .000 & adat pemilik \\
\hline 3. & Penampung kayu & 177 & 1.500 .000 & 265.500 .000 & hak ulayat \\
\hline
\end{tabular}

Sumber : KPHL Biak Numfor, 2015

Estimasi nilai manfaat ekonomi kayu yang diperoleh dari hutan-hutan di sekitar di kota Biak berkisar dari Rp. 4,9 milyar sampai dengan Rp. 220,5 milyar. Nilai tersebut berdasarkan harga kayu Rp. 1.500.000. Sedangkan harga kayu di kota Biak bervariasi mulai dari Rp. 700.000 sampai Rp. 2.000.000. Sehingga nilai kayu tersebut masih berpeluang naik lebih tinggi lagi. Bila dilihat dari jumlah uang yang dapat dibayarkan secara nominal kelihatan besar namun bila didistribusikan kepada masyarakat pemilik hak ulayat jumlah tersebut menjadi lebih kecil.

Usaha meubel kayu di kota Biak telah memanfaatkan jenis kayu damar sebagai bahan baku pembuatan berbagai jenis mebel. Dari data yang didapat di lapangan, ada terdapat dua meubel yang menerima penjualan kayu damar (Agathis labilaldieri Warb) dari masyarakat pemilik hak ulayat kampung Rimba Jaya yaitu meubel Biak Indah dan meubel Tondano Indah. Kayu tersebut dibeli dengan harga Rp. $1.500 .000 / \mathrm{m}^{3}$ untuk balok dan 2.000.000 per $\mathrm{m}^{3}$ untuk papan.
Dari kayu tersebut diolah menjadi produk-produk jadi seperti kursi, meja, lemari, tempat tidur, dan lain-lain tergantung produk yang dipesan.

Dalam skema berbasis dana manfaat hanya diperoleh dari marga-marga yang memiliki hak ulayat di kampung Rimba Jaya Distrik Biak Timur yaitu marga Simyapen, Usyor, dan Arompau. Ketiga marga tersebut yang sering menebang pohon damar sesuai dengan daerah hak milik mereka masing-masing. Banyaknya pohon yang derada di sekitar perumahan maryarakat kampung Rimba Jaya yang telah ditebang dari hasil penelitian langsung di lapangan berjumlah 180 pohon, yang terdiri dari 100 pohon yang sudah ditebang pada beberapa tahun yang lalu karena bekas (pangkal pohon) yang ditebang sudah mulai lapuk, sedangkan pohon damar yang baru saja ditebang mulai dari tahun 2014-2015 berjumlah 80 pohon, ini dilihat dari sisa-sisa kayu tersebut yang ditebang dan juga pengakuan masyarakat di sekitar kawasan hutan. 
Pemanfaatan kayu damar oleh masyarakat di kawasan hutan Rimba Jaya masih bersifat khusus untuk pemilik hak ulayat. Bila mengacu pada prinsip pembagian manfaat yang adil maka aliran manfaat yang diterima oleh masyarakat di kampung Rimba Jaya hanya berbasis hak yakni kepada pemilik hak ulayat seperti marga Simyapen, Usyor, dan Arompau. Sedangkan masyarakat yang bukan pemilik hak ulayat hanya merasakan manfaat tidak langsung dari upaya perlindungan dan pelestarian hutan damar serta mengakses kawasan hutan damar untuk kepentingan yang bersifat umum misalnya pemukiman. Distribusi manfaat (uang tunai) yang diterima dari hasil penjualan kayu damar sangat bergantung pada jumlah kayu yang dapat dikeluarkan dari areal yang menjadi hak waris anggota marga atau kelompok marga pemilik ulayat. Dengan demikian akan terdapat disparitas (kesenjangan) pendapatan di antara marga-marga pemilik hak ulayat dengan yang bukan pemilik. Distribusi pendapatan yang tidak merata dalam masyarakat seperti ini merupakan salah satu alasan pemerintah untuk menguasai sumberdaya hutan (Yustika 2006).

Sekalipun dari sisi manfaat bersifat eksklusif dan distribusinya belum merata, namun dari sisi hak kepemilikan menunjukkan adanya pengakuan yang semakin menguat terhadap keberadaan hak-hak masyarakat hukum adat. Sebab secara umum dipercaya bahwa Property rights (hak kepemilikan) yang lebih baikekslusif, enforceable, transferable, akan mendorong investasi dan peningkatan efisiensi produksi demikian hak kepemilikan akan mempengaruhi perilaku dan kesempatan pihak yang memilikinya (Grafton et al. 2000).
Jika uang pembayaran kayu dipandang sebagai ganti rugi atas kepemilikan sumberdaya hutan yang merupakan milik masyarakat hukum adat maka dana tersebut jauh lebih tinggi nilainya dibandingkan dengan dana kompensasi hasil hutan kayu yang selama ini dibayarkan IUPHHK (Ijin Usaha Pemanfaatan Hasil Hutan Kayu) kepada pemilik hak ulayat. Artinya bahwa masyarakat akan untung jika menjual kayu ke pemilik kios kayu, meubel dibandingkan kalau menerima kompensasi hasil hutan kayu.

Aktivitas penebangan dilakukan oleh masyarakat pemilik hak ulayat apabila ada kebutuhan yang bersifat mendesak atau menyangkut pelayanan publik. Misalnya menjelang hari raya natal, adanya permasalahan denda adat, kedukaan dan lain-lain. Sedangkan untuk kepentingan publik pada kawasan hutan damar telah dibangun 1 unit sekolah dasar dan beberapa rumah masyarakat.

\section{Skema Berbasis Kelola Dampak}

Kelola dampak merupakan skema pembagian manfaat pada wilayah hutan damar yang diterima masyarakat lokal atau pemilik hak ulayat terkait dengan kegiatan-kegiatan pemeliharaan dan pelestarian kawasan hutan yang rusak. Kegiatan ini dilakukan sebagai dampak dari aktivitas penebangan pohon yang juga berdampak terhadap rusaknya vegetasi sekitar.

Hutan damar (Agathis labilaldieri Warb) yang berada di kampung Rimba Jaya ini pada awalnya jumlahnya sangat banyak, namun seiring perkembangan jaman dan jumlah penduduk yang semakin meningkat serta desakan kebutuhan ekonomi yang semakin meningkat maka dilakukan penebangan terhadap pohon-pohon damar tersebut. 
Banyaknya pohon yang sudah ditebang dari hasil penelitian langsung di lapangan berjumlah 180 pohon, yang terdiri dari 100 pohon yang sudah ditebang pada beberapa tahun yang lalu karena bekas yang ditebang sudah mulai lapuk, sedangkan pohon damar yang baru saja ditebang mulai dari tahun 2014 dan 2015 berjumlah 80 pohon, ini dilihat dari sisa-sisa kayu tersebut dan juga pengakuan masyarakat di sekitar kawasan hutan. Penebangan pohon damar ini yang dihasilkan dalam bentuk setengah jadi berupa papan dan balok, dan dijual perkubik seharga Rp. 1.500 .000 untuk balok dan Rp. 2.000.000 untuk papan.

Selain sebagai kayu olahan, pohon damar juga diambil ranting, dahan dan batang untuk keperluan bahan bakar. Namun untuk keperluan ini biasanya dilarang kecuali untuk kegiatan-kegiatan gereja dan kegiatan budaya setempat. Berdasarkan wawancara pada masyarakat kampung Rimba Jaya biasanya mengambil kayu bakar damar dari pohon damar (Agathis labilaldieri Warb). Menurut masyarakat kampung Rimba Jaya kayu, damar tersebut bila dibakar akan menghasilkan nyala api yang baik, sehingga masyarakat suka memanfaatkan kayu damar sebagai kayu bakar bagianbagian dari kayu damar yang dimanfaatkan sebagai kayu bakar seperti batang, ranting, dan kulit. Dalam pemanfaatan kayu damar sebagai kayu bakar masyarakat kampung Rimba Jaya tidak bisa memperjual belikan kayu bakar dari pohon damar kepada orang lain atau para pembeli lainnya, karena dalam pengambilan kayu damar sebagai bahan bakar (kayu bakar) dilarang keras oleh masyarakat pemilik hak ulayat.

Bentuk pembagian manfaat yang dilakukan adalah dengan melibatkan masyarakat dalam kegiatan rehabilitasi hutan dan lahan di dalam kawasan hutan damar. Masyarakat dilibatkan sebagai penyedia bibit dengan harga $\mathrm{Rp}$. 200/bibit. Penerimaaan dari setiap masyarakat yang terlibat dalam penyediaan bibit berdasarkan jumlah bibit yang dihasilkan. semakin banyak bibit yang dihasilkan semakin tinggi jumlah uang yang diterima. Manfaat yang diterima tidak hanya secara ekonomi tetapi juga manfaat ekologi yaitu karena adanya pemulihan lingkungan masyarakat kampung Rimba Jaya mendapatkan udara yang segar $\left(\mathrm{O}_{2}\right)$, sumber air bersih $\left(\mathrm{H}_{2} \mathrm{O}\right)$, menjaga kesuburan tanah, mengurangi erosi, tanah longsor dan lain-lain.

\section{Kegiatan Penanaman/Rehabilitasi}

Pada hutan damar ada pohon-pohon yang dikhususkan menjadi pohon induk penghasil benih untuk ditanam. Pohon damar ini dipilih karena pohon tersebut dilihat sehat dan dapat menjadi pohon induk yang mampu menghasilkan benih damar yang baik pula, dan pohon damar tersebut ditandai dengan menggunakan nomor di sebuah plat pada batang pohon damar dengan menggunakan cat. Pohon damar ini berdia meter 50 dan tinggi mencapai 40-50 m, memiliki daun dan buah yang sehat serta produsi getahnya juga banyak, maka pohon damar tersebut dipilih sebagai pohon induk penghasil benih damar

Dari data yang didapatkttan di lapangan, bahwa ada kegiatan penanaman bibit pohon damar yang dilakukan oleh Pemerintah Provinsi Papua (Dinas Kehutanan dan Konservasi) dalam bentuk pembangunan demplot jenis tegakan endemik papua dan pemerintah Kabupaten 
Tabel 3. Perbandingan skema pembagian manfaat di beberapa tempat

\begin{tabular}{|c|c|c|c|c|}
\hline Jenis Manfaat & $\begin{array}{c}\text { Investor } \\
\text { Kehutanan } \\
\text { Teluk Bintuni }\end{array}$ & $\begin{array}{r}\text { IPKMA di } \\
\text { Manokwari }\end{array}$ & $\begin{array}{c}\text { Hutan } \\
\text { Kemasyarakatan } \\
\text { di Nepal }\end{array}$ & $\begin{array}{c}\text { Hutan } \\
\text { Damar di } \\
\text { Biak } \\
\text { Timur }\end{array}$ \\
\hline Berbasis Uang & $\sqrt{ }$ & $\sqrt{ }$ & $\sqrt{ }$ & $\sqrt{ }$ \\
\hline Berbasis Pasar & $\sqrt{ }$ & - & - & - \\
\hline Berbasis Infrastruktur & $\sqrt{ }$ & & $\sqrt{ }$ & - \\
\hline Kelola Sosial & $\sqrt{ }$ & $\sqrt{ }$ & $\sqrt{ }$ & - \\
\hline $\begin{array}{l}\text { Transfer Pengetahuan dan } \\
\text { Teknologi }\end{array}$ & $\sqrt{ }$ & - & $\sqrt{ }$ & - \\
\hline Biaya Administrasi & - & - & $\sqrt{ }$ & - \\
\hline $\begin{array}{lll}\text { Jaminan } & \text { Sosial dan } \\
\text { Kemiskinan } & & \end{array}$ & - & - & $\sqrt{ }$ & - \\
\hline Dana Pembangunan Hutan & & & $\sqrt{ }$ & - \\
\hline Berbasis Kelola Dampak & - & - & - & $\sqrt{ }$ \\
\hline
\end{tabular}

Sumber : Tokede dkk. 2005; Marwa 2014.

Biak Numfor (Kesatuan Pengelolaan Hutan Lindung) Dalam meningkatkan peran serta masyarakat dalam merehabilitasi Hutan dan lahan. penanamanan bibit ini dilaksanakan oleh dinas Kehutanan Provisi Papua pada Tahun 2006 pada luasan lahan yan ditanam $10 \mathrm{Ha}$, sedangkan penanaman yang ke dua yang dilaksanakan oleh
KPHL Biak Numfor pada tahun 2014 melalui anggaran Otonomi Khusus dengan luasan lahan 2,5 Ha. Kegiatan melibatkan masyarakat pemilik hak wilayat yang diketua oleh Bapak Leopord Simyapen dan anggota yang terdiri dari 20 orang yang juga merupakan masyarat pemilik hak wilayat dan masyarakat yang berada disekitar hutan damar tersebut.

Tabel 4. Syarat pembagian manfaat berdasarkan prinsip keadilan

\begin{tabular}{lcc}
\hline \multirow{2}{*}{ Pemenuhan Syarat } & \multicolumn{2}{c}{ Skema Pembagian Manfaat } \\
\cline { 2 - 3 } & Berbasis Uang & Berbasis Kelola dampak \\
\hline Equality & - & + \\
Equity & - & - \\
Needs-base & + & - \\
Berbasis Hak & + & - \\
Pro Poor & - & + \\
Transparency & + & + \\
Additionality & + & - \\
\hline
\end{tabular}

Keterangan : + memenui syarat ; - : tidak memenuhi syarat

Manfaat adalah segala sesuatu yang dapat membuat seseorang atau sekelompok orang diuntungkan atau seseorang yang diberikan sesuatu dan oleh karenanya kesejahterannya meningkat, maka orang tersebut diuntungkan (better off). Sebaliknya seseorang akan merasa dirugikan (worse off) apabila sejumlah manfaat diambil daripadanya (Field 1999). Dalam konteks 
pemanfaatan sumberdaya hutan di hutan damar kampung Rimba Jaya terdapat sejumlah manfaat yang diberikan oleh pengusaha atau perusahaan dan pemerintah dalam hal ini dinas kehutanan kepada masyarakat. Aliran manfaat tersebut diberikan dalam skema berbasis uang, dan skema berbasis kelola dampak. Skema ini masih jauh berbeda bila dibandingkan dengan skema yang pernah dan sedang dipraktekan di beberapa tempat. Skema berbasis uang atau dana dipraktekan pada semua tempat seperti pada Tabel 3 Sedangkan skema lainnya bersifat spesifik tergantung kebutuhan dan situasi dimana aktivitas pemanfaatan dan pengelolaan hutan dilalukan.

Skema pembagian manfaat yang dipratekan dalam pemanfaatan hutan damar di wilayah kampung Rimba Raya masih sangat minim oleh sebab itu tidak belum efisien dan efektif untuk menjaga kelestarian kawasan hutan damar tersebut. Bila mengacu kepada prinsip-prinsip keadilan sebagaimana disajikan pada Tabel 4, maka skema pembagian manfaat dilakukan di kawasan hutan damar Biak Timur hanya yang berbasis uang saja yang cukup efisien sedangkan berbasis kelola dampak belum efisien karena hanya beberapa kriteria saja yang terpenuhi.

Skema pembagian manfaat berbasis uang sudah efisien karena dalam skema ini ada praktek transparansi pembayaran kayu antara pembeli dalam hal ini kios kayu dan mebel dengan masyarakat pemilik. Disisi lain dari skema ini juga manfaat hanya berbasis hak yakni kepada pemilik hak ulayat. Selain itu, syarat pemenuhan kebutuhan dasar (Needs base) dan peningkatan nilai tambah juga terdapat dalam skema berbasis dana. Pemenuhan kebutuhan dasar ini terlihat dalam biaya pendidikan, biaya perayaan natal dan biaya-biaya urusan adat. Sedangkan nilai tambah terlihat dari perubahan harga kayu di kota Biak yang terus-menerus mengalami peningkatan termasuk kayu damar.

Namun diantara masyarakat adat sendiri aspek kesetaraan (equality), aspek keadilan (equity) dan pro poor (mendukung orang-orang miskin) tidak terjadi. Karena jumlah hasil penjualan tidak sama rata untuk semua pemilik kayu, juga tidak semua masyarakat adat bisa mengakses hutan damar untuk memenuhi kebutuhan terutama bagi masyarat miskin dan rentan terhadap kemiskinan. Artinya kelompok masyarakat cenderung dipisahkan berdasarkan hak (heterogen dalam hak). Kondisi ini ini berbeda dengan praktek pembagian manfaat di kabupaten Sarmi Papua, dimana dalam pembagian dana kompensasi dirinci lagi berdasarkan Peraturan Bupati Kabupaten Sarmi No. 40 Tahun 2007 dengan pembagian sebagai berikut: $65 \%$ dimiliki oleh pemilik hak ulayat /blok tebangan, pemilik TPK/Logyard (8\%), pembinaan $7 \%$ dan dan sisanya masing-masing $5 \%$ untuk jalan, material penimbunan jalan, base camp, dan loading point. Sebelumnya dengan SK yang sama pemilik hak ulayat/blok tebang mendapat $70 \%$, material penimbunan jalan $7 \%$, jalan 7\%, base camp 7\%, TPK logyard $7 \%$ dan adat $2 \%$ (Marwa dkk. 2010).

Terdapat tiga belas stakeholders yang dapat terlibat dalam pembagian manfaat sumberdaya hutan di kabupaten Biak Numfor. ketiga belas stakeholders tersebut terdiri dari pemerintah provinsi (Dinas Kehutanan, Dinas Perindustrian dan Perdagangan, Kepala Marga, Pemilik Hak Ulayat, LSM, tokoh agama, tokoh 
pemuda, swasta, kepala kampung, LMA Biak Numfor, kepala distrik, masyarakat pendatang,dan KPHL Biak Numfor )

Stakeholders dalam pembagian manfaat sumberdaya hutan memiliki kepentingan (interest) serta pengaruh (power) yang beragam, ada yang bersifat positif dan sejalan dengan tujuan pembagian manfaat yang adil, adapula yang bersifat negatif dan bertentangan dengan tujuan yang akan dicapai. Kepentingan (interest) dan pengaruh (power) dari stakeholders dalam pembagian manfaat yang beragam perlu dipetakan dengan jelas. Pemetaan stakeholders akan membantu bagaimana melibatkan stakeholders tersebut dalam pencapaian tujuan pembagian manfaat yang adil (Nkhata et al. 2009). Berdasarkan pengaruh (power) dan kepentingan (interest) yang dimiliki oleh setiap stakeholders maka stakeholders yang terlibat dalam pembagian manfaat dapat dikategorikan menjadi empat jenis yaitu (Nkhata et al. 2009; Gardner et al. 1986):

1. Stakeholder dengan tingkat kepentingan (interest) yang tinggi tetapi memiliki pengaruh (power) yang rendah diklasifikasikan sebagai subyek. Dinas Kehutanan Kabupaten dan Pengusaha kayu. Stakeholders ini memiliki kapasitas yang rendah dalam pencapaian tujuan, akan tetapi dapat menjadi berpengaruh dengan membentuk aliansi stakeholders lainnya.Stakeholder ini sering dapat sangat membantu sehingga hubungan dengan stakeholders ini harus tetap dijaga dengan baik.

2. Stakeholder dengan tingkat kepentingan (interest) dan pengaruh (power) yang tinggi diklasifikasikan sebagai Pemain Kunci (Key Players). Stakeholders ini harus lebih aktif dilibatkan secara penuh termasuk dalam mengevaluasi strategi baru, karena mereka berperan dalam merumuskan kebijakan pembagian manfaat yang adil dan melakukan monitoring dan evaluasi terhadap kebijakan pembagian manfaat. terdiri dari pemilik hak ulayat, masyarakat adat, Dishut Provinsi, Dishut Kabupaten Biak Numfor dan KPHL.

3. Stakeholder dengan tingkat kepentingan (interest) dan pengaruh (power) yang rendah diklasifikasikan sebagai pengikut lain (crowd). Diperlukan sedikit pertimbangan untuk melibatkan stakeholders ini lebih jauh karena kepentingan dan pengaruh yang dimiliki biasanya berubah seiring berjalannya waktu. Stakeholders ini harus tetap dimonitor dan dijalin komunikasi dengan baik. Stakeholders ini antara lain Dinas Perindustrian dan Perdagangan, Kepala Marga, LSM, tokoh agama, tokoh pemuda, , kepala distrik, masyarakat pendatang.

4. Stakeholder dengan tingkat kepentingan (interest) yang rendah tetapi memiliki pengaruh (power) yang tinggi diklasifikasikan sebagai pendukung (contest setters). Hubungan baik dengan stakeholder terus dibina. Untuk itu informasi yang dibutuhkan harus tetap diberikan sehingga mereka dapat terus berperan aktif dalam pencapaian tujuan. Stakeholders ini terdiri dari kepala kampung, LMA Biak Numfor. 


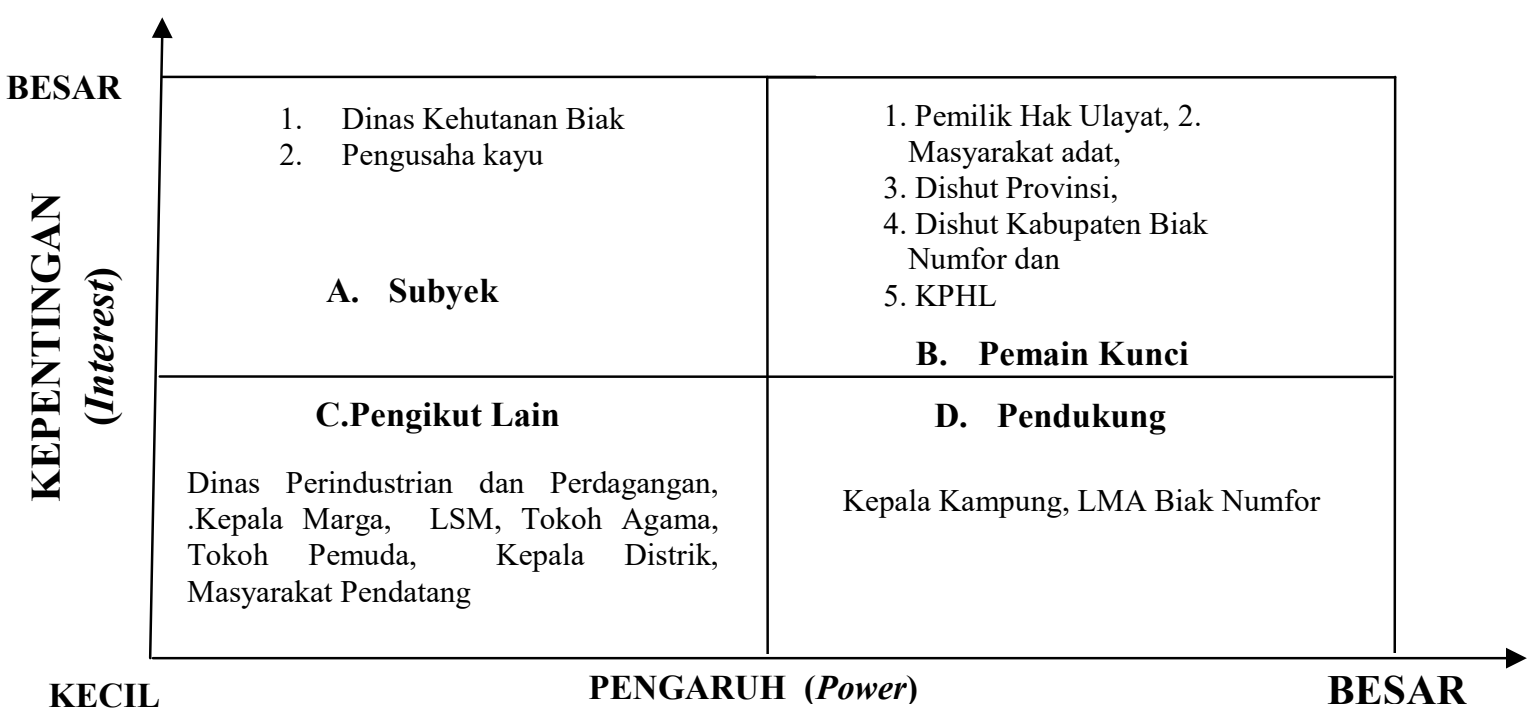

Gambar 2. Pemetaan stakeholders berdasarkan pengaruh (power) dan kepentingannya (interest) dalam skema pembagian manfaat sumberdaya hutan dammar.

Pengabaian terhadap keterlibatan stakeholders lain sebagai pemain kunci dapat menciptakan asimetrik informasi (ketidasedianan informasi). Situasi asimetrik informasi akan menyebabkan kerjasama diantara para pihak rentan terhadap resiko salah memilih mitra dan bahaya ingkar janji (moral hazard). Salah satu bahaya ingkar janji adalah munculnya perilaku oportunis (Opportunistic behavior). Perilaku oportunis terjadi apabila salah satu pihak memanfaatkan kelebihan informasi yang dimiliki untuk mengeksploitasi pihak lain (Barney and Ouchi, 1986). Apabila situasi oportunis terjadi maka pemain kunci lain akan melakukan perlawanan dengan membentuk aliansi dan pada suatu saat menjadi sumber/pemicu konflik sebagai upaya untuk memperlihatkan eksistensinya.

\section{DAFTAR PUSTAKA}

Barney JB and Ouchi WG. 1986. Organizational Economics. Jossey-
Bass Inc., Publishers. California. USA.

Field BC. 1994. Environmental Economics: An Introduction. McGraw Hill. Inc. USA.

Gardner, J. R., Rachlin, R. and Sweeny, H.W.A. (1986).Handbook of Strategic

Planning.http://www.12manage. com/methods stakeholder mapping.html. Akses $\quad$ Tgl. 17 Oktober 2014.

Grafton, R. Q., Squires, D., and Fox, K. J. 2000. Private Property and Economic Efficiency: A Study of a CommonPool Resource. Journal of Law and Economics, 43(2): 679-713.

Marwa J. Purnomo H, Nurochmat D.R. 2010. Managing The Last Frontier of Indonesiaan Forest in Papua. Faculty of Forestry Bogor Agricultur University and Asean - Korea Enviromental Cooperation. Bogor.

Marwa J. 2015. Adilkah Skema Pembagian Manfaat Hutan Bagi Masyarakat Adatdi Kawasan Teluk 
Bintuni?Policy Brief. Jaringan Peneliti Kawasan Timur Indonesia ( JiKTI). Makassar.

Nkhata BA, Mosimane A, Downsborough L, Breen C and Roux DJ. 2012. A typology of benefit sharing arrangements for the governance of social-ecological systems in developing countries. Ecology and Society $17(1)$ : 17. http://dx.doi.org/10.5751/ES-04662$\underline{170117}$

Tokede, M. Nugroho. Gandhi, Y. 2005. Polycy Brief: Akses Masyarakat Adat Terhadap Peluang-peluang Pembangunan Kehutanan di Kabupaten Manokwari.Cifor. Bogor Yustika E.A. 2006. Ekonomi Kelembagaan: Defenisi, Teori dan
Strategi. Bayumedia Publishing. Malang.

Mohammed EY. 2011. Pro-poor distribution in REDD+: Who gets what and why does it matter. Redd Working Paper. London: IIED.

Wagstaff GF. 1994. Equality: equity and need. Three principles of justice or one? An analysis of equity as desert. Current psychology, 13(2): 138-152.

Maiese EM. 2003. Distribution justice. In: burges, $G$ and Burgess, H. (Eds.). Beyond intractability conflict research consortium. Boulder: The university of Colorado. Available at: http://www.beyondintractability.org/e ssay/types-of-justice [Accessed: 2019, June 15]. 